\title{
Effects of the duration of exposure to hormone supplements on cytoplasmic maturation of pig oocytes in vitro
}

\author{
H. Funahashi and B. N. Day* \\ Department of Animal Science, University of Missouri-Columbia, Columbia, MO 65211, USA
}

\begin{abstract}
The effect of hormone supplements on cytoplasmic maturation in vitro was examined by incubating oocyte-cumulus complexes in a medium with PMSG ( $10 \mathrm{iu} \mathrm{ml}^{-1}$ ), hCG (10 iu $\mathrm{ml}^{-1}$ ) and oestradiol $\left(1 \mu \mathrm{g} \mathrm{ml}^{-1}\right.$ ) for various periods and then transferring them to medium without added hormones for the remainder of the maturation period. Exposure of oocyte-cumulus complexes to hormone supplements for $2 \mathrm{~h}$ improved only germinal vesicle breakdown and maturation rates compared with complexes not exposed to added hormones. The removal of hormone supplements at $20 \mathrm{~h}$ after the start of culture enhanced the ability of oocytes to form male pronuclei 10 to $12 \mathrm{~h}$ after insemination. Further, the effects of transfer of intact and oocytectomized oocyte-cumulus complexes to hormone-free medium at $20 \mathrm{~h}$ on cumulus expansion were examined. The diameter and morphology of the intact oocytecumulus complexes were improved after the removal of oocyte-cumulus cell complexes from hormonal exposure. The responses of oocytectomized oocyte-cumulus complexes to hormone were similar to those of intact oocyte-cumulus complexes with the exception of corona radiata expansion. The results suggest that the removal of hormone supplements from maturation media at $20 \mathrm{~h}$ after culture enhanced cytoplasmic maturation and cumulus expansion. Further, cumulus expansion does not appear to depend on intercellular communication between cumulus cells and oocytes. Oocytectomy did influence expansion of the corona radiata during culture.
\end{abstract}

\section{Introduction}

Pig follicular oocyte-cumulus complexes have been cultured in media supplemented with several combinations of hormones: PMSG, hCG and oestradiol (Yoshida et al., 1990, 1992; Wang et al., 1991); FSH, LH, prolactin and oestradiol (Mattioli et al., 1988a); FSH, LH and oestradiol (Zheng and Sirard, 1992); FSH, LH and prolactin (Mattioli et al., 1988b; Nagai and Moor, 1990); FSH and LH (Mattioli ef al., 1990, 1991; Galeati et al., 1991); LH and oestradiol (Nagai et al., 1988); FSH (Naito et al., 1988); and LH (Nagai $e t$ al., 1990; Mattioli et al., 1991). The addition of hormone supplements into maturation media enhances nuclear maturation and cumulus expansion of the oocyte-cumulus complexes (Meinecke and Meinecke-Tillmenn, 1979; Hillensjo and Channing, 1980; Minato and Toyoda, 1982; Yoshida et al., 1989; Prochazka et al., 1991). In addition, the supplementation of FSH together with follicular fluid (Naito et al., 1988) or the addition of LH with follicular shells (Mattioli et al, 1991) improves cytoplasmic maturation as determined by male pronuclear formation. In control or superovulated pigs, the concentrations of gonadotrophins and steroids in follicular fluid change dramatically during preovulatory oocyte maturation (Moor, 1974; McNatty et al., 1975; Hunter et al., 1976; Ainsworth et al., 1980; Lenton et al., 1988). Oocyte maturation in vivo is induced by the preovulatory surge of gonadotrophins via granulosa

${ }^{*}$ Correspondence.

Received 15 June 1992 cells (Eppig, 1991) and also cumulus expansion can be induced with FSH or LH (Hillensjo and Channing, 1980). Cytoplasmic maturation is considered to require a strictly regulated sequence of hormonal changes during maturation (Osborn and Moor, 1983). The change in hormonal concentration during maturation, therefore, may be of considerable importance for the secretory activity of cumulus cells, a subset of granulosa cells. Consequently, meiotic or cytoplasmic maturation of oocytes may be affected indirectly by the degree and duration of hormonal exposure of cumulus cells.

The present study was undertaken to examine the effects of timed exposure of pig oocyte-cumulus complexes to hormone supplements on the cumulus expansion and male pronuclear formation after in vitro fertilization. Furthermore, the effect of intercellular communication between cumulus cells and oocytes on cumulus expansion was determined by culture of intact and oocytectomized oocyte-cumulus complexes.

\section{Materials and Methods}

\section{Culture media}

The basic medium (mM199) for the manipulation of oocytes and spermatozoa was Medium 199 with Earle's salts (Gibco BRL, Life Technologies Inc., Grand Island, NY) supplemented with $3.05 \mathrm{mmol}$ D-glucose $\mathrm{I}^{-1}$ (Sigma Chemical Co., St Louis,

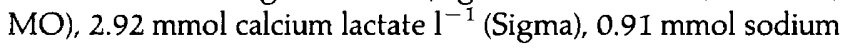


pyruvate $1^{-1}$ (Sigma), $75 \mu \mathrm{g}$ potassium penicillin $\mathrm{G} \mathrm{ml} \mathrm{ml}^{-1}$ (Sigma) and $50 \mu \mathrm{g}$ streptomycin sulphate $\mathrm{ml}^{-1}$ (Sigma). The basic medium for oocyte maturation (OMM199) was mM199 supplemented with hormonal supplements, which were 10 iu PMSG ml ${ }^{-1}$ (Intervet America Inc., DE), $10 \mathrm{iu} \mathrm{hCG} \mathrm{\textrm {ml } ^ { - 1 }}$ (LyphoMed Inc., Rosemont, IL), $1 \mu \mathrm{g}$ oestradiol $\mathrm{ml}^{-1}$ (Sigma) and $10 \%(\mathrm{v} / \mathrm{v})$ porcine follicular fluid $(\mathrm{pFF})$. The hormone supplements were added according to previous reports (Yoshida et al., 1990; Wang et al., 1991; Yoshida et al., 1992). pFF was used in the present study because in preliminary experiments pFF, rather than fetal calf serum (FCS), was shown to be a better supplement for maturation medium (Funahashi and Day, 1993). pFF was collected with oocyte-cumulus complexes used in this study from superficial follicles, $3-6 \mathrm{~mm}$ in diameter, of prepubertal pig ovaries within 4 to $6 \mathrm{~h}$ after slaughter. Thereafter, pFF was heat inactivated for $30 \mathrm{~min}$ at $56^{\circ} \mathrm{C}$, filtered through 1.2 and $0.45 \mu \mathrm{m}$ syringe filters and stored at $-20^{\circ} \mathrm{C}$ until use.

\section{Preparation and culture of follicular oocytes}

Ovaries were collected from prepubertal gilts at a local abattoir. Transportation of ovaries to the laboratory was carried out at $25^{\circ} \mathrm{C}$ in Dulbecco's phosphate-buffered saline supplemented with $5.54 \mathrm{mmol} D$-glucose $1^{-1}, 0.33 \mathrm{mmol}$ sodium pyruvate $\mathrm{I}^{-1}, 75 \mu \mathrm{g}$ potassium penicillin $\mathrm{G} \mathrm{ml}^{-1}$ and $50 \mu \mathrm{g}$ streptomycin sulfate $\mathrm{ml}^{-1}$ (mDPBS). Oocytes were aspirated through an 18-gauge needle into a disposable $10 \mathrm{ml}$ syringe from follicles 3-6 mm in diameter. Oocyte-cumulus complexes with uniform ooplasm and a compact cumulus cell mass were collected in mDPBS with $2 \%(\mathrm{v} / \mathrm{v})$ newborn piglet serum and then washed three times with OMMI99 pregassed in a $\mathrm{CO}_{2}$ incubator (in an atmosphere of $5 \% \mathrm{CO}_{2}$ in air) at $39^{\circ} \mathrm{C}$ for more than $3 \mathrm{~h}$. Ten oocyte-cumulus complexes were transferred to a droplet of $100 \mu \mathrm{l}$ of OMM199 covered with paraffin oil in a culture dish (Falcon, Beckton Dickinson and Co., Lincoln Park, NJ), which were pregassed in a $\mathrm{CO}_{2}$ incubator at $39^{\circ} \mathrm{C}$ for more than $3 \mathrm{~h}$, and then cultured at $39^{\circ} \mathrm{C}$ in an atmosphere of $5 \% \mathrm{CO}_{2}$ in air. At $0,2,20,30$ and $40 \mathrm{~h}$ after the start of culture, the oocytecumulus complexes were cultured in OMM199 without PMSG, hCG and oestradiol for $40,38,20,10$ and $O h$, respectively.

\section{Sperm preparation}

Sperm-rich fractions ( $15 \mathrm{ml}$ ) were collected from a boar by the gloved hand method, and after adding antibiotics $(75 \mu \mathrm{g}$ potassium penicillin $\mathrm{G} \mathrm{m} \mathrm{m}^{-1}$ and $50 \mu \mathrm{g}$ streptomycin sulfate $\mathrm{ml}^{-1}$ ) the semen samples were kept at $20^{\circ} \mathrm{C}$ for $16 \mathrm{~h}$ (Cheng, 1985). Thereafter, the semen was washed three times with $0.9 \%$ $\mathrm{NaCl}$ plus $10 \mathrm{mg} \mathrm{BSA} \mathrm{ml}^{-1}$ (fraction $\mathrm{V}$, Sigma) by centrifugation ( $1200 \mathrm{~g}$ for $3 \mathrm{~min}$ ) to remove seminal plasma. At the end of washing, the spermatozoa were resuspended at $2 \times 10^{8}$ cells $\mathrm{ml}^{-1}$ in mM199 at $\mathrm{pH} 7.8$ and supplemented with $10 \%$ FCS. The sperm suspension was preincubated for $90 \mathrm{~min}$ at $39^{\circ} \mathrm{C}$ in an atmosphere of $5 \% \mathrm{CO}_{2}$ in air.

\section{In vitro fertilization}

After $40 \mathrm{~h}$ of culture, oocytes were used for in vitro fertilization. The ten oocyte-cumulus complexes were washed three times with mM199 at $\mathrm{pH} 7.4$ supplemented with $10 \mathrm{mmol}$ caffeine sodium benzoate $\mathrm{l}^{-1}$ and $10 \% \mathrm{FCS}$, and then placed into a droplet of $50 \mu \mathrm{l}$ of the $\mathrm{mM} 199$ under paraffin oil, which had been pregassed in a $\mathrm{CO}_{2}$ incubator at $39^{\circ} \mathrm{C}$ for more than $3 \mathrm{~h}$. The dish was placed in an incubator at $39^{\circ} \mathrm{C}$ in $5 \% \mathrm{CO}_{2}$ in air until spermatozoa were added for insemination. Preincubated spermatozoa, $50 \mu \mathrm{l}$, were added to $50 \mu \mathrm{l}$ of medium containing oocytes following dilution from $2 \times 10^{8}$ cells $\mathrm{ml}^{-1}$ to $2 \times 10^{6}$ cells $\mathrm{ml}^{-1}$ with mM199 at $\mathrm{pH} 7.8$ and supplemented with $10 \%$ FCS (final sperm concentration: $1 \times 10^{6}$ cells $\mathrm{ml}^{-1}$ ). Oocytes were cultured with spermatozoa for 10 to $12 \mathrm{~h}$ at $39^{\circ} \mathrm{C}$.

\section{Assessment of cytoplasmic maturation}

At the end of the culture following insemination, eggs were removed from the droplet and aspirated in $4 \mathrm{ml} \mathrm{mDPBS}$ supplemented with $0.1 \%$ hyaluronidase to remove cumulus cells and supernumerary spermatozoa from the zona pellucida. Thereafter, eggs were mounted, fixed for $48 \mathrm{~h}$ or more in $25 \%(\mathrm{v} / \mathrm{v})$ acetic alcohol at room temperature, stained with $1 \%(\mathrm{w} / \mathrm{v})$ orcein in $45 \%(\mathrm{v} / \mathrm{v})$ acetic acid and examined under a phasecontrast microscope at $\times 400$ magnification. The meiotic stage of the oocytes was assessed according to Hunter and Polge (1966). Oocytes at the stage of anaphase I to metaphase II were regarded as matured. Oocytes were designated as penetrated when they had at least one swollen sperm nucleus or a male pronucleus and corresponding sperm tail in the vitellus. Those oocytes with more than one swollen sperm nucleus or male pronucleus were considered to be polyspermic.

\section{Measurement of cumulus diameter and assessment of cumulus expansion}

The effects of changes in hormonal culture conditions during maturation on cumulus expansion were examined by culturing oocyte-cumulus complexes in OMM199 without hormone supplements (group A), in OMM199 for $20 \mathrm{~h}$ with added hormones followed by culture with no hormones (group B) or in OMM199 with hormones (group C) in a droplet covered with warm paraffin oil. Each droplet contained one oocyte-cumulus complex. Cumulus cell expansion was evaluated by measurement of cumulus diameter and assessment of the degree of cumulus expansion after $0,20,30$ and $40 \mathrm{~h}$ of culture. The diameter of a single oocyte-cumulus complex was determined by measuring minimum and maximum diameter with an eye piece micrometer under stereomicroscope at $\times 40$ magnification and by calculating a mean diameter as (minimum diameter + maximum diameter) $\times 2^{-1}$. The degree of cumulus expansion was assessed according to a subjective scoring system from 0 to 4 as described by Vanderhyden et al. (1990).

\section{Oocytectomy}

The effect of intercellular communication between cumulus cells and oocytes on the enhanced cumulus expansion by removal of added hormones at $20 \mathrm{~h}$ was determined by removing oocytes microsurgically from oocyte-cumulus complexes (oocytectomy) after aspiration from follicles and washing with mDPBS supplemented with $2 \%(\mathrm{v} / \mathrm{v})$ newborn piglet serum. The micromanipulation technique, with minor modification, was the method 
Table 1. Effect of duration of exposure of pig oocyte-cumulus complexes to hormonal supplements in maturation medium on male pronuclear formation after fertilization in vitro

\begin{tabular}{|c|c|c|c|c|c|c|c|}
\hline \multicolumn{2}{|c|}{ Duration of culture (h) } & \multirow{2}{*}{$\begin{array}{l}\text { Number of } \\
\text { oocytes } \\
\text { examined }\end{array}$} & \multicolumn{3}{|c|}{ Number of oocytes } & \multirow{2}{*}{$\begin{array}{c}\text { Number }(\%) \text { of } \\
\text { polyspermic } \\
\text { oocytes }^{6}\end{array}$} & \multirow{2}{*}{$\begin{array}{l}\text { Number }(\%) \text { of } \\
\text { oocytes with } \\
\text { male and female } \\
\text { pronuclei }{ }^{6}\end{array}$} \\
\hline $\begin{array}{l}\text { With } \\
\text { hormones }^{1}\end{array}$ & $\begin{array}{l}\text { Without } \\
\text { hormones }^{2}\end{array}$ & & $\begin{array}{l}\mathrm{GVBD}^{3} \\
(\%)\end{array}$ & $\begin{array}{c}\text { Matured }^{4} \\
(\%)\end{array}$ & $\begin{array}{c}\text { Penetrated } \\
(\%)\end{array}$ & & \\
\hline 0 & 40 & 93 & $62(67)^{a}$ & $50(54)^{\mathrm{a}}$ & $32(64)^{a}$ & $25(78)^{a}$ & $5(16)^{a}$ \\
\hline 2 & 38 & 81 & $73(90)^{b}$ & $61(75)^{b}$ & $56(92)^{b}$ & $49(88)^{\mathrm{ab}}$ & $16(29)^{\mathrm{ab}}$ \\
\hline 20 & 20 & 106 & $106(98)^{c}$ & $97(90)^{c}$ & $93(96)^{b}$ & $88(95)^{b}$ & $62(67)^{c}$ \\
\hline 30 & 10 & 120 & $118(98)^{c}$ & $112(93)^{c}$ & $103(92)^{b}$ & $93(90)^{\mathrm{ab}}$ & $40(39)^{b}$ \\
\hline 40 & 0 & 111 & $110(99)^{c}$ & $88(88)^{c}$ & $94(96)^{b}$ & $89(95)^{b}$ & $34(36)^{b}$ \\
\hline
\end{tabular}

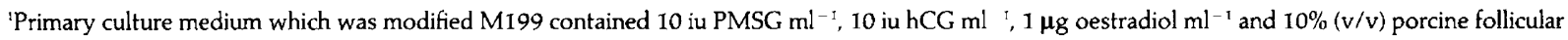
fluid.

${ }^{2}$ Secondary culture medium was the primary culture medium without PMSG, hCG and oestradiol.

${ }^{3}$ Germinal vesicle breakdown.

${ }^{4}$ The oocytes at the stage of anaphase I to metaphase II were regarded as matured.

${ }^{5}$ In matured oocytes.

${ }^{6}$ In penetrated oocytes.

Different superscripts within columns denote significant differences $(P<0.05)$.

described by Buccione et al. (1990) and Prochazka et al. (1991). Briefly, each oocyte-cumulus complex was held in the end of a holding pipette in $100 \mu \mathrm{l}$ droplet of mDPBS supplemented with $2 \%(\mathrm{v} / \mathrm{v})$ newborn piglet serum. A thin aspirating micropipette was then introduced through the ooplasm into the lumen of the holding pipette. After the tip of the aspirating micropipette was drawn back and replaced in the ooplasm, the ooplasm was aspirated into the holding and aspirating pipettes by a burst of negative pressure. Usually 10 to 15 oocytectomized oocytecumulus complexes were prepared within $15 \mathrm{~min}$. Each of the oocytectomized and control intact oocyte-cumulus complexes was cultured in a $50 \mu \mathrm{l}$ droplet of OMM199 for primary $20 \mathrm{~h}$ culture and then in a $50 \mu \mathrm{l}$ droplet of OMM199 without hormone supplements for a second $20 \mathrm{~h}$ period. The morphology and diameter of oocyte-cumulus complexes were recorded.

\section{Statistical analysis}

Treatment effects on cytoplasmic maturation were determined by examining averages of four replicate trials for statistical differences using $\chi^{2}$ analysis. A total of four replicate trials were conducted to determine the effects of changes in hormonal conditions on cumulus expansion. The effects of oocytectomy on cumulus expansion were determined by three separate trials. The mean diameter of oocyte-cumulus complexes in each experimental group was expressed as mean \pm SD. $\chi^{2}$ test and Student's $t$ test were used to determine statistical differences in morphology and diameter of oocyte-cumulus complexes, respectively. Probability of $P<0.05$ was considered to be statistically significant.

\section{Results}

\section{Cytoplasmic maturation}

There were no differences in the sperm penetration of pig oocytes among replicate trials in the present study. After 10 to
$12 \mathrm{~h}$ in co-culture with spermatozoa, differences in the ability of pig oocytes to form male pronuclei were related to the time of removal of hormone supplements from maturation medium (Table 1). Male pronuclear formation rate was significantly enhanced $(P<0.05)$ by removing hormone supplements at $20 \mathrm{~h}$ after the start of culture $(67 \%)$. The pronuclear formation rates of oocytes cultured with hormone supplements for $30 \mathrm{~h}$ and for the complete duration of culture $(39$ and $36 \%$, respectively) were not different from eggs exposed to the supplements for only $2 \mathrm{~h}(29 \%)$. Although germinal vesicle breakdown, maturation and sperm penetration occurred when oocytecumulus complexes were cultured in a medium without hormone supplements, an initial $2 \mathrm{~h}$ exposure of oocyte-cumulus complexes to hormone supplements significantly improved these traits (Table 1). When oocyte-cumulus complexes were exposed to the hormone supplements for more than $20 \mathrm{~h}$, there were no differences in germinal vesicle breakdown, maturation, sperm penetration or polyspermy rates. In all treatment groups, a high percentage $(75-95 \%)$ of polyspermic penetration was observed (Table 1).

\section{Cumulus expansion}

The morphology of cumulus expansion (the degree; 0 to 1 ) and the mean diameter $(260 \pm 39 \mu \mathrm{m}$ at $\mathrm{O} \mathrm{h}$ to $250 \pm 85 \mu \mathrm{m}$ at $40 \mathrm{~h}$ ) of oocyte-cumulus complexes showed little change during a $40 \mathrm{~h}$ culture when the oocyte-cumulus complexes were cultured in a medium without hormone supplements (group A). However, when oocyte-cumulus complexes were exposed to hormone supplements for at least $20 \mathrm{~h}$ (group B and C), expansion was enhanced by increased duration of culture (Fig. I and Table 2). At 30 and $40 \mathrm{~h}$ of culture, the mean diameter $(820 \pm 247 \mu \mathrm{m}$ and $1076 \pm 433 \mu \mathrm{m}$, respectively) of oocytecumulus complexes removed from exposure to hormone supplements after $20 \mathrm{~h}$ (group B) was larger $(P<0.05)$ than that $(620 \pm 178 \mu \mathrm{m}$ and $755 \pm 264 \mu \mathrm{m}$, respectively) of oocytecumulus complexes cultured continuously in the presence of 


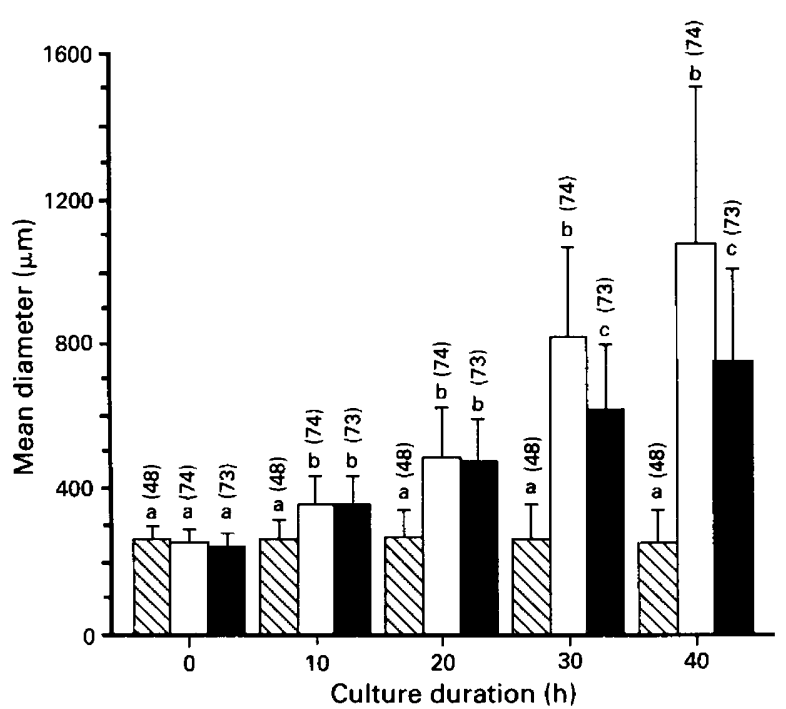

Fig. 1. The effects of duration of exposure of oocyte-cumulus complexes to hormone supplements on cumulus expansion. Individual oocyte-cumulus complexes were cultured in a droplet of hormone-free medium (Group A; $⿴$ ) for $40 \mathrm{~h}$, one in medium supplemented with hormones (PMSG, hCG and oestradiol) for first $20 \mathrm{~h}$ and then moved to hormone free medium for a further $20 \mathrm{~h}$ (Group B; $\square$ ), and one in medium with the hormones for $40 \mathrm{~h}$ (Group $\mathrm{C} ; \mathbf{D}$ ). The diameter of each oocyte-cumulus complex was measured at $0,10,20,30$ and $40 \mathrm{~h}$ after culture. The bars are given as the means \pm SD from four experiments. Columns with different letter above the bars are significantly different among groups at the same observation point $(P<0.05)$. The numbers in parentheses on top of bars indicate the number of oocytecumulus complexes examined.

hormones (group C) (Fig. 1). More oocyte-cumulus complexes developed to the advanced morphological stage in group B than in group $C$ at 30 and $40 \mathrm{~h}$ after culture (Table 2), and some $(23 \%, 11$ of 48$)$ of the oocyte-cumulus complexes in group B had expanded corona radiata after culture, whereas none of the oocyte-cumulus complexes in group $\mathrm{C}$ had expanded corona radiata at that time.

When oocytectomized pig oocyte-cumulus complexes were cultured in a medium with hormone supplements for $20 \mathrm{~h}$ and then without added hormones for $20 \mathrm{~h}$, the mean diameter of the oocyte-cumulus complexes increased with the duration of culture $(391 \pm 99 \mu \mathrm{m}$ at $20 \mathrm{~h}, 827 \pm 167 \mu \mathrm{m}$ at $30 \mathrm{~h}$ and $991 \pm 211 \mu \mathrm{m}$ at $40 \mathrm{~h}$ ), and there were no significant differences between diameter of oocytectomized (the above) and intact oocyte-cumulus complexes $(436 \pm 106 \mu \mathrm{m}$ at $20 \mathrm{~h}$, $861 \pm 231 \mu \mathrm{m}$ at $30 \mathrm{~h}$ and $1176 \pm 360 \mu \mathrm{m}$ at $40 \mathrm{~h}$ ) (Fig. 2). After $30 \mathrm{~h}$ of culture, the morphology of cumulus expansion in the oocytectomized group was similar to that of intact oocytecumulus complexes (Table 3). However, none of the corona radiata of oocytectomized oocyte-cumulus complexes underwent expansion at $40 \mathrm{~h}$ after culture, whereas $17 \%$ (9 of 52 ) of intact oocyte-cumulus complexes had expanded corona radiata.

\section{Discussion}

In the present study, we found that removal of hormone supplements (PMSG, hCG and oestradiol) from maturation medium at $20 \mathrm{~h}$ after the start of culture improved the ability of pig oocytes to form a male pronucleus 10 to $12 \mathrm{~h}$ after insemination. The exposure of oocyte-cumulus complexes to the supplements for only $2 \mathrm{~h}$ enhanced germinal vesicle breakdown and maturation of the oocytes, and nearly all of the oocytes showed meiotic maturation after exposure to hormones for $20 \mathrm{~h}$ or longer. These results suggest that there are at least two different phases during in vitro maturation, i.e. meiotic maturation is controlled by stimulation from hormone supplements in the primary phase $(20 \mathrm{~h})$ and cytoplasmic maturation is enhanced by the absence of some or all of the hormone supplements in the second $20 \mathrm{~h}$. Pig oocytes complete germinal vesicle breakdown in vivo and in vitro about $20 \mathrm{~h}$ after hCG injection (Hunter and Polge, 1966; Ainsworth et al., 1980) or culture (Naito and Toyoda, 1991). It appears therefore that the requirement of hormone supplementation is limited to the germinal vesicle breakdown phase. In vivo, concentrations of gonadotrophins and steroids in follicular fluid change dramatically during oocyte maturation (Moor, 1974; McNatty et al., 1975; Hunter et al., 1976; Ainsworth et al., 1980; Lenton et al., 1988), and, in particular, the concentration of oestrogens in prepubertal gilts declines rapidly between 4 and $16 \mathrm{~h}$ after hCG injection (Ainsworth et al., 1980). It is possible that these hormonal changes affect cytoplasmic maturation of the oocytes, although we did not examine the effects of removing each hormone supplement on cytoplasmic maturation in the present study. Further, our use of pFF derived from superficial follicles ( 3 to $6 \mathrm{~mm}$ in diameter) of prepubertal gilts, as a supplement for maturation media, would supply not only proteins but also a basal amount of the gonadotrophins and oestradiol. However, these hormonal contents in $\mathrm{pFF}$ were not determined. Naito et al. (1988) have reported that only $36 \%$ of oocytes matured when pig oocytes were cultured for $48 \mathrm{~h}$ in $\mathrm{pFF}$ which was derived from medium-sized follicles $(2-5 \mathrm{~mm}$ in diameter) of gilt ovaries.

The addition of follicular fluid with FSH during the in vitro maturation period $(48 \mathrm{~h})$ enhances male pronuclear development at $18 \mathrm{~h}$ after insemination (39 versus 61\%; Naito et al., 1988). In the present study, however, the male pronuclear formation rate of oocytes at 10 to $12 \mathrm{~h}$ after insemination was very low $(36 \%)$ when the oocytes were cultured in a medium supplemented with hormones and $10 \%$ follicular fluid for $40 \mathrm{~h}$ before insemination. The low pronuclear formation rate in the present study may be due to the reduced duration of the culture period for maturation because the male pronuclear formation rate was $59 \%$ at 10 to $12 \mathrm{~h}$ after insemination when oocyte-cumulus complexes were cultured in the same medium for $50 \mathrm{~h}$ before insemination (Funahashi and Day, 1993). Our results therefore suggest that a short exposure to hormones may advance the time of male pronuclear formation. In like manner, the supplementation of follicular shells during maturation in vitro (Mattioli et al., 1988a, 1991) improves the rate of formation of a male pronucleus in oocytes at $10 \mathrm{~h}$, as well as at $18 \mathrm{~h}$, after insemination (Moor et al., 1990).

We also found that removal of hormone supplements $20 \mathrm{~h}$ after culture enhanced the cumulus expansion of oocytecumulus complexes after $30 \mathrm{~h}$ of culture compared with that of oocyte-cumulus complexes cultured with hormones for $30 \mathrm{~h}$. Cumulus expansion results when cumulus cells secrete hyaluronic acid which expands the spaces between the cumulus cells (Eppig, 
Table 2. Effects of removal of hormone supplements in maturation medium on cumulus expansion of pig cumulusoocyte complexes

\begin{tabular}{|c|c|c|c|c|c|c|c|c|}
\hline \multirow{2}{*}{$\begin{array}{l}\text { Time of } \\
\text { observation } \\
\text { (h of culture) }\end{array}$} & \multirow{2}{*}{$\begin{array}{l}\text { Experimental } \\
\text { group }^{1}\end{array}$} & \multirow{2}{*}{$\begin{array}{l}\text { Number of } \\
\text { oocytes } \\
\text { examined }\end{array}$} & \multicolumn{5}{|c|}{ Degree of cumulus expansion ${ }^{2}(\%)$} & \multirow{2}{*}{$\begin{array}{c}\text { Cumulus } \\
\text { expansion } \\
\text { index }^{3}\end{array}$} \\
\hline & & & 0 & 1 & 2 & 3 & 4 & \\
\hline \multirow[t]{3}{*}{0} & A & 48 & $48(100)$ & $0 \quad(0)$ & $0 \quad(0)$ & $0 \quad(0)$ & $0(0)$ & 0.00 \\
\hline & $\mathrm{B}$ & 48 & $48(100)$ & $0 \quad(0)$ & $0 \quad(0)$ & $0 \quad(0)$ & $0 \quad(0)$ & 0.00 \\
\hline & C & 48 & $48(100)$ & $0 \quad(0)$ & $0 \quad(0)$ & $0 \quad(0)$ & $0 \quad(0)$ & 0.00 \\
\hline \multirow[t]{3}{*}{10} & A & 48 & $48(100)$ & $0 \quad(0)^{\mathrm{a}}$ & $0 \quad(0)$ & $0 \quad(0)$ & $0(0)$ & 0.00 \\
\hline & $\mathrm{B}$ & 48 & $0 \quad(0)$ & $48(100)^{\mathrm{b}}$ & $0 \quad(0)$ & $0(0)$ & $0(0)$ & 1.00 \\
\hline & $\mathrm{C}$ & 48 & $2 \quad(4)$ & $46(96)^{b}$ & $0(0)$ & $0 \quad(0)$ & $0 \quad(0)$ & 0.96 \\
\hline \multirow[t]{3}{*}{20} & A & 48 & $46 \quad(96)$ & $2 \quad(4)$ & $0 \quad(0)^{a}$ & $0 \quad(0)$ & $0 \quad(0)$ & 0.04 \\
\hline & B & 48 & $\begin{array}{ll}0 & (0)\end{array}$ & $8 \quad(17)$ & $40(83)^{b}$ & $0 \quad(0)$ & $0 \quad(0)$ & 1.83 \\
\hline & $\mathrm{C}$ & 48 & $0 \quad(0)$ & $7 \quad(15)$ & $41(85)^{b}$ & $0 \quad(0)$ & $0 \quad(0)$ & 1.85 \\
\hline \multirow[t]{3}{*}{30} & A & 48 & $44 \quad(92)$ & (8) & $0 \quad(0)$ & $0(0)^{\mathrm{a}}$ & $0 \quad(0)$ & 0.08 \\
\hline & B & 48 & $0 \quad(0)$ & (0) & $11(23)$ & $37(77)^{\mathrm{b}}$ & $0 \quad(0)$ & 2.77 \\
\hline & C & 48 & $0 \quad(0)$ & (0) & $25(52)$ & $23(48)^{c}$ & $0 \quad(0)$ & 2.48 \\
\hline \multirow[t]{3}{*}{40} & A & 48 & $35 \quad(73)$ & $13(27)$ & $0 \quad(0)$ & $0 \quad(0)$ & $0(0)^{a}$ & 0.27 \\
\hline & B & 48 & $0 \quad(0)$ & $0 \quad(0)$ & 36 & $34(71)$ & $11(23)^{b}$ & 3.17 \\
\hline & C & 48 & $0 \quad(0)$ & (0) & $5(10)$ & $43(90)$ & $0(0)^{a}$ & 2.90 \\
\hline
\end{tabular}

'Cumulus-oocyte complexes were cultured in OMM199 without hormones for $40 \mathrm{~h}$ (group A), in OMM199 for $20 \mathrm{~h}$ with added hormones followed by culture with no hormones for $20 \mathrm{~h}$ (group B) or in OMM199 with hormones for $40 \mathrm{~h}$ (group C).

${ }^{2} 0$, no detectable response; 1 , minimum observable response; 2 , expansion limited to the outer layer of cumulus cells; 3 , cumulus expansion except the corona radiata; 4 , maximum degree of expansion; i.e. the cumulus oophorus and corona radiata have undergone expansion.

${ }^{3}$ Mean degree of cumulus expansion.

Different superscripts within columns at each time of observation denote significant difference $(P<0.05)$.

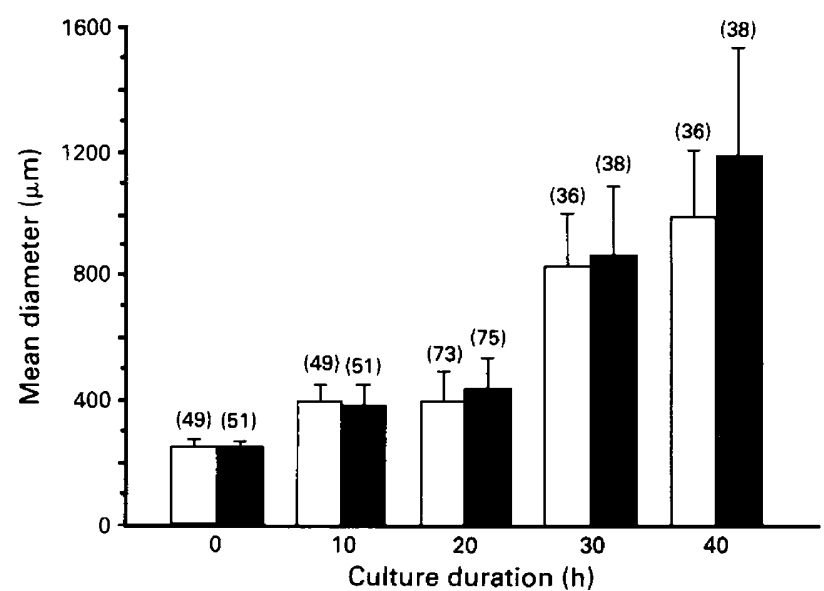

Fig. 2. The effects of oocytectomy on cumulus expansion. Individual intact oocyte-cumulus complexes $(\boldsymbol{\square})$ or oocytectomized oocytecumulus complexes $(\square)$ were incubated in a droplet of medium supplemented with hormones (PMSG, hCG and oestradiol) for $20 \mathrm{~h}$ and then moved into a droplet of hormone-free medium for $20 \mathrm{~h}$. The diameter of each complex was measured at $0,10,20,30$ and $40 \mathrm{~h}$ after culture. The bars are given as the mean \pm SD from three experiments. There were no significant differences between intact and oocytectomized groups. The numbers in parentheses on top of bars indicate the number of oocyte-cumulus complexes tested.

1991). The degree of cumulus expansion as measured by the mean diameter of cumulus oophorus can therefore be regarded as a marker of the metabolic abilities of cumulus cells. The present results suggest that the placement of oocyte-cumulus complexes in hormone-free medium at about $20 \mathrm{~h}$ after culture enhances the secretory potential of cumulus cells. McNatty et al. (1975) suggested that the hormonal changes during maturation may be of considerable importance for secretory activity of the granulosa cells both before and after ovulation. However, Mattioli et al. (1988b) reported that, when oocyte-cumulus complexes were cultured in medium conditioned by follicle walls, an active intercellular communication between cumulus cells and oocyte was seen for 30 to $40 \mathrm{~h}$ of culture, although decreasing at $32 \mathrm{~h}$ after culture, which is similar to that of oocytes matured in vivo (Motlik et al., 1986). Although the change of intercellular communication in media supplemented with follicular fluid and hormones has not been examined, it is possible that the intercellular communication is maintained by the metabolic stimulation of cumulus cells caused by the change of hormonal conditions during the second half of maturation culture.

In mice, in which cumulus expansion is stimulated directly by FSH in vitro, it is known that oocytectomized oocyte-cumulus complexes fail to show cumulus expansion in response to FSH (Buccione et al., 1990). Since medium conditioned by isolated oocytes induced hyaluronic acid synthesis by isolated cumulus cells (Salustri et al., 1990) and increased the expansion of oocytectomized complexes (Buccione et al., 1990), it is considered that mouse oocytes produce the expansion enabling factor(s), and the oocyte participates in the regulation of cumulus cell function (Buccione et al., 1990). In the present study, when pig oocyte-cumulus complexes were exposed to hormone supplements for the initial $20 \mathrm{~h}$ of the culture, oocytectomized 
Table 3. Effects of oocytectomy on cumulus expansion of pig cumulus-oocyte complexes

\begin{tabular}{|c|c|c|c|c|c|c|c|c|}
\hline \multirow{2}{*}{$\begin{array}{l}\text { Time of } \\
\text { observation } \\
\text { (h of culture) }\end{array}$} & \multirow{2}{*}{$\begin{array}{c}\text { Experimental } \\
\text { group }\end{array}$} & \multirow{2}{*}{$\begin{array}{l}\text { Number of } \\
\text { oocytes } \\
\text { examined }\end{array}$} & \multicolumn{5}{|c|}{ Degree of cumulus expansion ${ }^{2}(\%)$} & \multirow{2}{*}{$\begin{array}{c}\text { Cumulus } \\
\text { expansion } \\
\text { index }^{3}\end{array}$} \\
\hline & & & 0 & 1 & 2 & 3 & 4 & \\
\hline \multirow[t]{2}{*}{30} & Oocytectomy ${ }^{1}$ & 50 & $O(0)$ & $0(0)$ & $4 \quad(8)$ & $46(92)$ & $0 \quad(0)$ & 2.92 \\
\hline & Intact & 52 & $0(0)$ & $0(0)$ & $5(10)$ & $47(90)$ & $0(0)$ & 2.90 \\
\hline \multirow[t]{2}{*}{40} & Oocytectomy & 50 & $O(0)$ & $0(0)$ & $2(4)$ & $48(96)$ & $0(0)$ & 2.96 \\
\hline & Intact & 52 & $O(0)$ & $0(0)$ & $4 \quad(8)$ & $39(75)$ & $9(17)$ & 3.10 \\
\hline
\end{tabular}

'Oocyte-cumulus complexes were removed from the oocyte by micromanipulation at the start of culture.

${ }^{2} 0$, no detectable response; 1 , minimum observable response; 2 , expansion limited to the outer layer of cumulus cells; 3 , cumulus expansion except the corona radiata; 4, maximum degree of expansion; i.e. the cumulus oophorus and corona radiata have undergone expansion.

${ }^{3}$ Mean degree of cumulus expansion.

oocyte-cumulus complexes did not exhibit expansion of corona radiata $40 \mathrm{~h}$ after culture, whereas some of the intact oocytecumulus complexes showed full cumulus expansion. Prochazka et al. (1991) compared the expansion of oocytectomized oocytecumulus complexes with that of intact oocyte-cumulus complexes $24 \mathrm{~h}$ after culture and concluded that cumulus expansion of oocyte-cumulus complexes did not require the cumulus expansion-enabling factor from oocytes. Our results, however, indicate that intercellular communication with oocytes is necessary for the expansion of corona radiata during the latter half of maturation, even though expansion of cumulus cells except for corona radiata does not depend on the interaction with the oocytes. On reflection, the failure of corona radiata expansion in the oocyte-cumulus complexes that were cultured with hormones for $40 \mathrm{~h}$ may be due to deficient intercellular communication due to hormones. As no more than $23 \%$ of oocytes reached expansion grade 4 in any treatment groups in the present study, our culture conditions during in vitro maturation appear not to be optimal for the expansion of corona radiata. Further investigations to determine suitable conditions for full expansion of corona radiata may increase the ability of pig oocytes to form a male pronucleus after in vitro fertilization.

In the present study, the incidence of polyspermic penetration was very high in all treatment groups. A high incidence of polyspermy in pig oocytes has been observed by many investigators (Nagai et al., 1984; Cheng, 1985; Mattioli et al., 1988a). Mattioli et al. (1989) reported that $53 \%$ of penetrated oocytes were polyspermic when ten to fifteen oocytes were cultured in $2 \mathrm{ml}$ of fertilization medium containing $1 \times 10^{5}$ spermatozoa ml ${ }^{-1}$ for 6 to $8 \mathrm{~h}$. Our higher incidence of polyspermic entry may be due to a higher sperm concentration $\left(1 \times 10^{6}\right.$ cells $\left.^{-1}\right)$ in a small volume $(100 \mu \mathrm{l})$ of fertilization medium, or to exposure of oocytes to spermatozoa for longer duration, 10 to $12 \mathrm{~h}$, or to both factors. Rath (1992) reported that there was a correlation between the number of inseminated spermatozoa per oocyte and the incidence of polyspermy. Further, Cheng (1985) found that a longer period (more than $8 \mathrm{~h}$ ) of incubating oocytes with spermatozoa results in a significant increase in polyspermy. As Wang et al. (1991) expressed, high incidence of polyspermy in pig oocytes matured in vivo suggests that polyspermy is not due entirely to abnormality of oocytes matured in vitro.
In summary, we demonstrated that the transfer of pig oocyte-cumulus complexes from medium supplemented with hormones to hormone-free medium at $20 \mathrm{~h}$ after culture enhanced the cytoplasmic maturation of pig oocytes, which was evaluated by the ability of the oocytes to form a male pronucleus after in vitro fertilization. Removal of hormones from the culture medium also stimulated cumulus expansion during in vitro maturation. Furthermore, expansion of cumulus cells, except for the corona radiata, did not depend on the intercellular communication with oocytes.

The authors thank B. Nichols for secretarial assistance with the preparation of this manuscript. H. Funahashi is the recipient of University of Missouri Miller Fund and Food for the 21st century postdoctoral fellowship. This manuscript is a contribution from the Missouri Agricultural Experimental Station: Journal Series Number 11, 692.

\section{References}

Ainsworth L, Tsang BK, Downey BR, Marcus GJ and Armstrong DT (1980) Interrelationships between follicular fluid steroid levels, gonadotropic stimuli, and oocyte maturation during preovulatory development of porcine follicles Biology of Reproduction 23 621-627

Buccione R, Vanderhyden BC, Caron PJ and Eppig JJ (1990) FSH-induced expansion of the mouse cumulus oophorus in vitro is dependent upon a specific factor(s) secreted by the oocyte Developmental Biology 138 16-25

Cheng WTK (1985) In vitro Fertilization of Farm Animal Oocytes. PhD thesis, Council for National Academic Awards, London

Eppig JJ (1991) Intercommunication between mammalian oocytes and companion somatic cells BioEssays 13 569-574

Funahashi H and Day BN (1993) Effects of different serum supplements in maturation medium on meiotic and cytoplasmic maturation of pig oocytes Theriogenology 39 965-973

Galeati G, Modina S, Lauria A and Mattioli M (1991) Follicle somatic cells influence pig oocyte penetrability and cortical granule distribution Molecular Reproduction and Development 29 40-46

Hillensjo T and Channing CP (1980) Gonadotrophin stimulation of steroidogenesis and cellular dispersion in cultured porcine cumuli oophori Gamete Research 3 233-240

Hunter RHF and Polge C (1966) Maturation of follicular oocytes in the pig after injection of human chorionic gonadotrophin Joumal of Reproduction and Fertility 12 525-531

Hunter RHF, Cook B and Baker TG (1976) Dissociation of response to injected gonadotropin between the Graafian follicle and oocyte in pigs Nature $\mathbf{2 6 0}$ 156-158 
Lenton EA, King H, Thomas EJ, Smith SK, McLachlan RI, MacNeil S and Cooke ID (1988) The endocrine environment of the human oocyte Jourmal of Reproduction and Fertility $\mathbf{8 2}$ 827-841

McNatty KP, Hunter LM, McNeilly AS and Sawers RS (1975) Changes in the concentration of pituitary and steroid hormones in the follicular fluid of human Graafian follicles through the menstrual cycle Journal of Endocrinology $64555-571$

Mattioli M, Galeati G and Seren E (1988a) Effect of follicle somatic cells during pig oocyte maturation on egg penetrability and male pronucleus formation Gamete Research 20 177-183

Mattioli M, Galeati G, Bacci ML and Seren E (1988b) Follicular factors influence oocyte fertilizability by modulating the intercellular cooperation between cumulus cells and oocyte Gamete Research 21 223-232

Mattioli M, Bacci ML, Galeati G and Seren E (1989) Developmental competence of pig oocytes matured and fertilized in vitro Theriogenology 31 1201-1207

Mattioli M, Barboni B, Bacci ML and Seren E (1990) Maturation of pig oocytes: observations on membrane potential Biology of Reproduction 43 318-322

Mattioli M, Bacci ML, Galeati G and Seren E (1991) Effects of LH and FSH on the maturation of pig oocytes in vitro Theriogenology 36 95-105

Meinecke B and Meinecke-Tillmenn S (1979) Effects of gonadotropins on oocyte maturation and progesterone production by porcine ovarian follicles cultured in vitro Theriogenology 11 351-365

Minato $Y$ and Toyoda $Y$ (1982) Induction of cumulus expansion and maturation division of porcine oocyte-cumulus complexes in vitro Japanese Journal of Zootechnological Science 53 480-487

Moor RM (1974) The ovarian follicle of the sheep: inhibition of oestrogen secretion by luteinizing hormone Joumal of Endocrinology 61 455-463

Moor RM, Mattioli M, Ding J and Nagai T (1990) Maturation of pig oocytes in vivo and in vitro Joumal of Reproduction and Fertility Supplement 40 197-210

Motlik J, Fulka J and Flechon J-E (1986) Changes in intercellular coupling between pig oocytes and cumulus cells during maturation in vivo and in vitro Joumal of Reproduction and Fertility 76 31-37

Nagai T and Moor RM (1990) Effect of oviduct cells on the incidence of polyspermy in pig eggs fertilized in vitro Molecular Reproduction and Development 26 377-382

Nagai T, Niwa K and Iritani A (1984) Effect of sperm concentration during preincubation in a defined medium on fertilization in vitro of pig follicular oocytes Joumal of Reproduction and Fertility 70 271-275

Nagai T, Takahashi T, Masuda H, Shioya Y, Kuwayama M, Fukushima M Iwasaki $\mathbf{S}$ and Hanada $\mathbf{A}$ (1988) In-vitro fertilization of pig oocytes by frozen boar spermatozoa Journal of Reproduction and Fertility 84 585-591
Nagai T, Takahashi T, Shioya Y and Oguri N (1990) Maturation and fertilization of pig follicular oocytes cultured in pig amniotic fluid Theriogenology 34 $195-204$

Naito K and Toyoda Y (1991) Fluctuation of histone H1 kinase activity during meiotic maturation in porcine oocytes Joumal of Reproduction and Fertility $\mathbf{9 3}$ $467-473$

Naito K, Fukuda Y and Toyoda Y (1988) Effects of porcine follicular fluid on male pronucleus formation in porcine oocytes matured in vitro Gamete Research $\mathbf{2 1}$ 289-295

Osborn JC and Moor RM (1983) The role of steroid signals in the maturation of mammalian oocytes Journal of Steroid Biochemistry 19 133-137

Prochazka R, Nagyova E, Rimkevicova Z, Nagai T, Kikuchi K and Motlik J (1991) Lack of effect of oocytectomy on expansion of the porcine cumulus Joumal of Reproduction and Fertility 93 569-576

Rath D (1992) Experiments to improve in vitro fertilization techniques for in vivo-matured porcine oocytes Theriogenology 37 885-896

Salustri A, Yanagishita M and Hascall VC (1990) Mouse oocytes regulate hyaluronic acid synthesis and mucification by FSH-stimulated cumulus cells Developmental Biology 138 26-32

Vanderhyden BC, Caron PJ, Buccione R and Eppig JJ (1990) Developmental pattern of the secretion of cumulus expansion-enabling factor by mouse oocytes and the role of oocytes in promoting granulosa cell differentiation Developmental Biology 140 307-317

Wang WH, Niwa K and Okuda K (1991) In-vitro penetration of pig oocytes matured in culture by frozen-thawed ejaculated spermatozoa journal of Reproduction and Fertility 93 491-496

Yoshida M, Bamba K and Kojima Y (1989) Effects of gonadotropins and estradiol $17 \beta$ on the timing of nuclear maturation and cumulus mass expansion in pig oocytes cultured in vitro Japanese Journal of Animal Reproduction 35 86-91

Yoshida M, Ishizaki Y and Kawagishi $\mathbf{H}$ (1990) Blastocyst formation by pig embryos resulting from in-vitro fertilization of oocytes matured in vitro Journal of Reproduction and Fertility $\mathbf{8 8} 1-8$

Yoshida M, Ishigaki K and Pursel VG (1992) Effect of maturation media on male pronucleus formation in pig oocytes matured in vitro Molecular Reproduction and Development 31 68-71

Zheng YS and Sirard MA (1992) The effect of sera, bovine serum albumin and follicular cells on in vitro maturation and fertilization of porcine oocytes Theriogenology $37779-790$ 